\title{
Corrigendum: Brain asymmetry in the white matter making and globularity
}

\author{
Constantina Theofanopoulou * \\ Department of General Linguistics, Universitat de Barcelona, Barcelona, Spain \\ Keywords: brain asymmetry, white matter, lateralization, brain rhythms, language
}

\section{A corrigendum on}

OPEN ACCESS

Edited and reviewed by: Antonio Benítez-Burraco,

University of Huelva, Spain

*Correspondence: Constantina Theofanopoulou constantinaki@hotmail.com

Specialty section:

This article was submitted to

Language Sciences,

a section of the journal

Frontiers in Psychology

Received: 13 November 2015 Accepted: 16 November 2015 Published: 14 December 2015

Citation:

Theofanopoulou C (2015) Corrigendum: Brain asymmetry in the white matter making and globularity.

Front. Psychol. 6:1857. doi: 10.3389/fpsyg.2015.01857
Brain asymmetry in the white matter making and globularity

by Theofanopoulou, C. (2015). Front. Psychol. 6:1355. doi: 10.3389/fpsyg.2015.01355

In the Acknowledgments Section of the original Hypothesis \& Theory article, the last sentence erroneously reported grant number FFI2014-61888-EXP as part of funds supporting the work. The only grant was \#FFI2013-43823-P, provided by Spanish Ministry of Economy and Competitiveness.

This error does not change the scientific conclusions of the article in any way.

\section{ACKNOWLEDGMENTS}

I am indebted to Cedric Boeckx for his constant encouragement and help. Many thanks also to Antonio Benítez-Burraco for helpful discussion.

Conflict of Interest Statement: The author declares that the research was conducted in the absence of any commercial or financial relationships that could be construed as a potential conflict of interest.

Copyright $\odot 2015$ Theofanopoulou. This is an open-access article distributed under the terms of the Creative Commons Attribution License (CC BY). The use, distribution or reproduction in other forums is permitted, provided the original author(s) or licensor are credited and that the original publication in this journal is cited, in accordance with accepted academic practice. No use, distribution or reproduction is permitted which does not comply with these terms. 